\title{
Honoré de Balzac, Pene di cuore di una gatta inglese
}

\section{Marco Stupazzoni}

\section{(2) OpenEdition}

\section{Journals}

\section{Edizione digitale}

URL: http://journals.openedition.org/studifrancesi/6337

DOI: 10.4000/studifrancesi.6337

ISSN: 2421-5856

\section{Editore}

Rosenberg \& Sellier

\section{Edizione cartacea}

Data di pubblicazione: 1 novembre 2010

Paginazione: 565

ISSN: 0039-2944

\section{Notizia bibliografica digitale}

Marco Stupazzoni, «Honoré de Balzac, Pene di cuore di una gatta inglese», Studi Francesi [Online], 162 (LIV | III) | 2010, online dal 30 novembre 2015, consultato il 11 janvier 2021. URL: http:// journals.openedition.org/studifrancesi/6337 ; DOI: https://doi.org/10.4000/studifrancesi.6337

Questo documento è stato generato automaticamente il 11 janvier 2021.

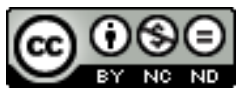

Studi Francesi è distribuita con Licenza Creative Commons Attribuzione - Non commerciale - Non opere derivate 4.0 Internazionale. 


\title{
Honoré de Balzac, Pene di cuore di una gatta inglese
}

\author{
Marco Stupazzoni
}

\section{NOTIZIA}

HONORÉ DE BALZAC, Pene di cuore di una gatta inglese, traduzione dal francese di Elga MUGELLINI, in AA. VV., Le più belle storie di gatti. Dai più grandi scrittori di ogni epoca, Torino, Edizioni «L'Età dell'Acquario», 2009, pp. 5-24.

1 Pubblicato in prima edizione nel febbraio del 1841 all'interno della miscellanea di racconti intitolata Scènes de la vie privée et publique des animaux (Hetzel et Paulin), Peines de coeur d'une chatte anglaise trova una giusta collocazione all'interno di questa originale raccolta di testi narrativi dedicati al gatto e scritti da alcuni dei più grandi scrittori di ogni epoca. Oltre al testo balzachiano, che inaugura il volume, figurano nella raccolta racconti di autori quali Poe, Gautier, Cechov, Kipling, Cattabiani ed altri. Quest'opera di Balzac ha avuto una discreta fortuna editoriale in Italia a partire dalla seconda metà dell'Ottocento: meritevoli di essere segnalati sono altresì alcuni adattamenti teatrali della novella, l'ultimo dei quali, sotto la direzione di Alfredo Arias, nel 1999, ha goduto di un notevole successo da parte della critica e del pubblico. 